\title{
Validitas Lks Matematika Dengan Pendekatan Saintifik Berbasis Outdoor Pada Materi Bangun Datar
}

\section{Riduan Febriandi}

Program Magister Pendidikan Dasar Universitas Bengkulu riduanfebriandi9@gmail.com

\section{Agus Susanta}

Program Magister Pendidikan Dasar Universitas Bengkulu

Wasidi

Program Magister Pendidikan Dasar Universitas Bengkulu

\begin{abstract}
Abstrak
Penelitian ini bertujuan untuk membuat sebuah produk berupa LKS matematika dengan pendekatan saintifik berbasis outdoor, serta untuk menghasilkan LKS yang valid sehingga dapat digunakan oleh peserta didik. Penelitian ini merupakan penelitian pengembangan, dimana model pengembangan diadaptasi dari model Borg dan Gall yang menuliskan 10 langkah Research and Development. Namun pada penelitian ini diadaptasi 6 langkah pengembangan mengingat keterbatasan waktu, biaya dan tenaga,yangterdiri dari: (1) penelitian dan pengumpulan informasi, (2) perencanaan, (3) pengembangan produk awal, (4) uji coba terbatas, (5) revisi produk awal, dan (6) uji coba lapangan. Hasil penelitian menunjukkan bahwa LKS matematika yang dikembangkan dan telah divalidasi oleh para ahli dengan kriteria valid dan reliabel, dimana kriteria validitas adalah tinggi yaitu, 0,913 dengan konsistensi ahli sedang 0,77, Rata-rata nilai peserta didik yang diperoleh setelah belajar menggunakan LKS lebih besar yaitu 80,35, sedangkan rata-rata nilai peserta didik dari guru tanpa menggunakan LKS sebesar 64,79. Secara umum LKS matematika dengan pendekatan saintifik berbasis outdoor untuk siswa kelas IV SD pada materi bangun datar yang dikembangkan valid digunakan dalam pembelajaran.
\end{abstract}

Kata kunci : LKS, saintifik, outdoor

\begin{abstract}
Abtsract
This study aims to make a product in the form of mathematical Student Workshet with an outdoor-based scientific approach, as well as to produce valid Student Workshet so that it can be used by students. This research
\end{abstract}


is a development research, where the development model is adapted from the Borg and Gall models which write 10 steps of Research and Development. But in this study adapted 6 development steps given the limitations of time, cost and energy, which consists of: (1) research and information gathering, (2) planning, (3) initial product development, (4) limited trials, (5) revisions initial product, and (6) field trial. The results showed that mathematical worksheets were developed and validated by experts with valid and reliable criteria, where the validity criteria were high, that is, 0.913 with moderate expert consistency of 0.77 , the average value of students obtained after learning using a larger Student Workshet namely 80.35, while the average value of students from teachers without using Student Workshet is 64.79. In general, mathematical Student Workshet with an outdoor-based scientific approach for fourth grade students of elementary school on a flat building material that was developed very validly was used in learning.

Keyword: Student Workshet, scientific, outdor

\section{Pendahuluan}

Mutu akademik antar bangsa melalui Programme for International Student Assessment (PISA) 2003 menunjukkan bahwa dari 41 negara yang di survei untuk bidang IPA, Indonesia menempati peringkat ke-38, sementara dibidang Matematika dan kemampuan membaca menampati peringkat ke-39. Kunandar (2007:8) mengatakan bahwa untuk menilai kualitas suatu bangsa secara umum dapat dilihat dari mutu pendidikan bangsa tersebut, sejarah telah membuktikan bahwa kemajuan dan kejayaan suatu bangsa di dunia ditentukan oleh pembangunan dibidang pendidikan. Meraka menganggap kebodohan adalah musuh kemajuan dan kejayaan suatu bangsa.

Dalam dunia pendidikan tidak akan lepas dengan proses belajar yang akan menghasilkan dan mencetak peserta didik yang diharapkan bangsa ini. Proses pembelajaran yang dilihat dengan realitas proses pendidikan saat ini, masih banyak pendidikan yang melaksanakan pembelajaran dengan menerapkan sistem pembelajaran konvensional, tidak mau susah payah memproduksi bahan ajar dalam merancang pembelajaran yang lebih inovatif.

Bahan ajar yang digunakan langsung pakai dengan membeli, bahan ajar yang instan tidak terencana secara sistematis karena tidak dibuat sendiri. Bahan ajar yang digunakan peserta didik tersebut kurang kontekstual karena tidak sesuai dengan kebutuhan peserta didik. Beberapa bahan ajar yang langsung pakai adalah berupa buku teks atau buku-buku panduan lain yang serupa dengan pelajaran di sekolah yang dijual di toko buku namun tidak sesuai dengan kompetensi dasar yang ada, dan juga buku sumbangan dari pemerintah.

Masih rendahnya kreatifitas dalam mengembangkan bahan ajar membuat pembelajaran kurang efektif dan efesien. Pembelajaran yang efektif, efesien dan menyenangkan bagi siswa tidak hanya belajar ceramah dan tanya jawab, melainkan harus diciptakannya inovasi-inovasi baru dengan menyesuaikan kebutuhan peserta didik melalui pembelajaran yang ilmiah. Dengan memanfaatkan berbagai bahan ajar selain buku sangat di sarankan bagi guru yang akan mengajar matematika agar pembelajaran lebih efektif, efesien, menyenangkan bagi siswa dan tidak membosankan. Bahan ajar yang dibuat sendiri akan lebih efektif digunakan dan terencana untuk diajarkan kepada siswa dalam memahami konsep-konsep pembelajaran matematika.

Salah satu bahan ajar selain buku ataupun media pelajaran yang efektif untuk diproduksi sendiri sesuai dengan tingkat dan kebutuhan siswa adalah Lembar Kerja Siswa (LKS). Menciptakan pembelajaran yang aktif dan efektif dapat dilakukan dengan mempersiapkan perangkat pembelajaran, salah satu komponen perangkat 
pembelajaran adalah lembar kerja siswa (LKS) yang berisi kegiatan pembelajaran yang melibatkan siswa, Hamdani (dikutip dalam Rodliyah, 2014:562).

Dijelaskan Prastowo (2015:8) bahwa LKS merupakan suatu bahan ajar cetak berupa lembar-lembar kertas yang berisi materi, ringkasan, dan petunjuk-petunjuk pelaksaan tugas pembelajaran yang harus dikerjakan oleh peserta didik yang mengacu pada kompetensi dasar yang harus dicapai. Sejalan dengan Trianto (2012:41) yang menyatakan bahwa menyatakan Lembar kerja siswa adalah panduan siswa yang digunakan untuk melakukan kegiatan atau pemecahan masalah. Lembar kerja siswa (LKS) merupakan bahan ajar cetak yang berupa lembaran-lembaran berisikan tugas-tugas dengan langkah kerjanya sehingga siswa dapat belajar mandiri atau dengan pendamping (guru). LKS akan lebih menarik jika diproduksi dengan pendekatan saintifik dan dapat juga dilakukan pembelajaran di luar kelas (outdoor).

Pembelajaran dengan pendekatan saintifik dijelaskan oleh Daryanto (2014:51), bahwa ia mengemukakan dalam bukunya pendekatan saintifik adalah proses pembelajran yang dirancang sedemikian agar peserta didik secara aktif mengkonstruk sebuah konsep, prinsip-prinsip melalui tahapan-tahapan mengamati (untuk mengidentifikasi masalah), merumuskan masalah, merumuskan hipotesa, mengumpulkan data dengan berbagai teknik untuk menganalisa data serta menarik kesimpulan dan mengkomunikasikan konsep, hukum yang ditemukan. Tak hanya dilakukan di dalam kelas, namun akan lebih bermakna jika dilakukan pembelajaran tersebut di luar kelas (outroor). Menurut Widiasworo (2017:81) jelas outdoor learning banyak memberikan peluang bagi perseta didik untuk merasa asyik dan senang dalam mengikuti kegiatan pembelajaran, kondisi demikian sagat mendukung bagi tercapainya penugasan kempetensi dalam pembelajaran.

Berdasarkan permasalahan tersebut, akan dilakukan penelitian dan pengambangan LKS Matematika dengan pendekatan saintifik berbasis outdoor untuk siswa kelas IV Sekolah Dasar pada materi bangun datar. LKS yang dijadikan media ajar dengan bahasa yang mudah dipahami peserta didik, dan juga mampu menjadi fungsi sebagai pengganti pendidik saat peserta didik belajar dirumah maupun bersama temannya. LKS mata pelajaran matematika yang dikemas dengan pendekatan saintifik yang dimaksudkan untuk memberikan pemahaman kepada peserta didik dalam mengenal atau mengamati, memahami berbagai materi menggunakan pendekatan ilmiah yang dapat dicari informasi dari berbagai sumber yang tidak bergantung pada peserta didik saja.

\section{Metode}

Jenis penelitian yang digunakan dalam penelitian ini adalah penelitian dan pengembangan atau dalam bahasa Inggrisnya Research and Development (R\&D). Menurut Borg dan Gall dalam Sugiyono (2016:28) bahwa $R \& D$ adalah model pengembangan pendidikan berdasarkan pada industri yang menggunakan temuantemuan penelitian dalam merancang produk dan prosedur baru. Dijelaskan juga bahwa Penelitian dan Pengembangan atau Research and Development adalah suatu metode penelitian yang digunakan dalam suatu penelitian untuk menghasilkan sebuah produk baru, model, prosedur, teknik, dan alat-alat yang didasarkan pada metode dan analisis dari permasalahan yang spesifik, Sugiyono (2016: 29).

Menurut Sugiyono (2016: 35-36) yang ditulis dalam bukunya mengatakan bahwa dalam mengembangkan metode penelitian $R \& D$ ada 10 langkah pengembangan yang harus dilakukan untuk menghasilkan suatu produk yang telah teruji, di kutip dari salah satu ilmuwan yaitu Borg dan Gall. Pada penelitian dan pengembangan ini diadaptasi 6 langkah pengembangan yaitu: (1) pengumpulan informasi dan potensi maslah, (2) perencanaan, (3) desain produk awal, (4) uji coba terbatas, (5) revisi produk, (6) uji coba lapangan. 


\section{Teknik Pengumpulan Data}

\section{Waktu, Tempat, Objek dan Subjek Penelitian}

Penelitian dan Pengembangan ini sebelum dilakukan uji lapanangan terlebih dahulu dilakukan uji terbatas di SD Negeri 57 Lubuklinggau. Hasil uji coba masingmasing tahapan dianalisis lebih lanjut untuk mengetahui kelayakan LKS sebelum dilakukan uji lapangan kebeberapa SD di Lubuklinggau. Waktu penelitian ini dilaksanakan pada 30 April hingga 31 Mei 2018. Tempat penelitian ini adalah SD Negeri 56 Lubuklinggau, SD Negeri 58 Lubuklinggau, dan SD Negeri 59 Lubuklinggau. Objek penelitian pengembangan ini adalah sebuah produk bahan ajar berupa LKS Matematika dengan pendekatan saintifik berbasis outdoor. Sedangkan yang menjadi subjek dalam penelitian ini adalah peserta didik kelas IV yang menjadi kelas eksperimen di SD Negeri $(56,58$, dan 59) Lubuklinggau.

\section{Data Penelitian}

Data pada penelitian ini meliputi data kualitatif dan data kuantitatif. Data kualitatif diperoleh dari lembar validasi ahli produk awal LKS Matematika yang dikembangkan Sedangkan data kuantitatif diperoleh dari hasil kegiatan siswa dalam LKS Matematika.

\section{Instrumen Penelitian}

Penelitian pengembangan ini menggunakan instrumen penelitian berupa lembar identifikasi kebutuhan, lembar validasi, dan instrument tes. Lembar identifikasi kebutuhan berupa pertanyaan atau wawancara kepada pendidik dan perserta didik untuk mengetahui permasalahan dan kebutuhan dalam pembelajaran matematika di SD. Lembar validasi ahli yang disusun dalam daftar pernyataan dikumpulkan dalam skala sangat kurang (1), kurang (2), baik (3) dan sangat baik (4). Instrumen tes disediakan dalam LKS yang digunakan untuk menganalisis keefektifan LKS yang terdiri 5 (Lima) pertanyaan dengan level menaksir $\left(\mathrm{C}_{3}\right)$, menyimpulkan $\left(\mathrm{C}_{4}\right)$, menghitung $\left(\mathrm{C}_{5}\right)$ dan memilih $\left(\mathrm{C}_{6}\right)$.

\section{Teknik Pengumpulan Data}

Teknik pengumpulan data yang digunakan dalam pengembangan LKS Matematika dengan pendekatan saintifik berbasis outdoor dalam meningkatkan pemahaman konsep pada pelajaran luas dan keliling persegi panjang, yaitu wawancara LembarValidasi

Wawancara dilakukan dengan tujuan untuk melakukan analisis kebutuhan terkait dengan LKS Matematika. Peneliti melakukan wawancara kepada guru kelas IV dan peserta didik kelas IV. Data ini dianalisis kemudian disimpulkan bahwa diperlukan pengembangan LKS Matematika dengan pendekatan saintifik berbasis outdoor.

Lembar validasi digunakan sebagai panduan bagi validator dalam menilai atau melakukan validasi terhadap produk LKS Matematika yang akan dikembangkan oleh peneliti. Lembar valildasi berisi pernyataan yang disusun berdasarkan indikator pengembangan LKS Matematika dengan pendekatan saintifik berbasis outdoor untuk siswa kelas IV Sekolah Dasar pada materi bangun datar.

\section{Tabel 1}

Instrumen Validasi Ahli

\begin{tabular}{|c|l|c|}
\hline \multirow{4}{*}{ Aspek } & \multicolumn{1}{c|}{ Indikator } & $\begin{array}{c}\text { Banya } \\
\mathbf{k}\end{array}$ \\
& & $\begin{array}{c}\text { Butir } \\
\end{array}$ \\
\hline \multirow{4}{*}{$\begin{array}{c}\text { Komponen } \\
\text { Kelayakan } \\
\text { Isi }\end{array}$} & Cakupan Materi & 3 \\
\cline { 2 - 3 } & Akurasi Materi & 4 \\
\cline { 2 - 3 } & Pendekatan Saintifik & 7 \\
\cline { 2 - 3 } & Saintifik Berbasis Outdoor & 2 \\
\cline { 2 - 3 } & Mengandung Wawasan Produktifitas & 2 \\
\hline
\end{tabular}




\begin{tabular}{|c|l|c|}
\hline \multirow{4}{*}{$\begin{array}{c}\text { Komponen } \\
\text { Kebahasaan }\end{array}$} & Komunikatif & 1 \\
\cline { 2 - 3 } & Lugas & 2 \\
\cline { 2 - 3 } & Kesesuaian Dengan Kaidah Bahasa Indonesia Yang & 2 \\
\cline { 2 - 3 } & Penggunaan Istilah Simbol dan Lambang & 2 \\
\hline \multirow{2}{*}{$\begin{array}{c}\text { Komponen } \\
\text { Tampilan }\end{array}$} & Penggunaan Huruf & 2 \\
\cline { 2 - 3 } & Tata Letak Isi Media & 2 \\
\cline { 2 - 3 } $\begin{array}{c}\text { Komponen } \\
\text { Penyajian }\end{array}$ & Desain Tampilan & 3 \\
\cline { 2 - 3 } & Peknik Penyajian & 2 \\
\cline { 2 - 3 } & Pendukung Pembelajaran & $\mathbf{4 7}$ \\
\hline
\end{tabular}

\section{Teknik Analisis Data}

\section{Uji Validitas}

Validitas isi suatu instrumen penelitian adalah ketepatan instrumen tersebut ditinjau dari segi materi yang akan diteliti. Validitas isi suatu instrumen tes berkenaan dengan kesesuaian butir soal dengan indikator kemampuan yang diukur, kesesuaian dengan kompetensi dasar materi yang diteliti dan materi yang diteskan representatif dalam mewakili keseluruhan materi yang diteliti.

Dalam menghitung validits isi aitem menggunakan formula Aiken's $V$ yang ditulis Azwar (2015:113). Tingkat kevalidan produk dapat dilihat berdasarkan kofesien Aiken's $V$.

Tabel 2

Kriteria Koefisien Aiken's $V$

\begin{tabular}{|c|c|c|}
\hline No & $\begin{array}{c}\text { Koefisien } \\
\text { Korelasi }\end{array}$ & $\begin{array}{c}\text { Interpretasi } \\
\text { Validitas }\end{array}$ \\
\hline 1 & $>0,80$ & Tinggi \\
\hline 2 & $0,60 \leq V<0,80$ & Cukup Tinggi \\
\hline 3 & $0,40 \leq V<0,60$ & Cukup \\
\hline 4 & $0 \leq V<0,40$ & Buruk \\
\hline
\end{tabular}

\section{Uji Konsistensi}

Uji konsistensi antar validator dilakukan untuk untuk melihat kekonsistenan validator dalam memberikan penilaian terhadap rancangan produk yang dikembangkan. Interpretasi konsistensi antar validator yang dikemukakan oleh McHugh (2012: 279):

Tabel 3

Interpretasi of Cohen's Kappa

\begin{tabular}{|c|c|c|}
\hline Nilai Kappa & $\begin{array}{c}\text { Level } \\
\text { Kesepakatan }\end{array}$ & $\begin{array}{c}\text { \% Data yang } \\
\text { Reliabel }\end{array}$ \\
\hline $0-.02$ & Tidak Ada & $0-4 \%$ \\
\hline $.21-.39$ & Kurang & $4-15 \%$ \\
\hline $.40-.59$ & Lemah & $15-35 \%$ \\
\hline $.60-.79$ & Sedang & $35-63 \%$ \\
\hline $.80-.90$ & Kuat & $64-81 \%$ \\
\hline Lebihdari .90 & Sangat Kuat & $82-100 \%$ \\
\hline
\end{tabular}




\section{Hasil Penelitian}

\section{Hasil Validasi Ahli}

LKS yang telah selesai dirancang dan lembar validasi diberikan kepada masing-masing ahli. Validasi ahli dilakukan untuk mendapatkan masukan dan saran sekaligus memberikan penilaian terhadap LKS yang telah dirancang menggunakan model skala Likert yaitu skor 1 sampai 4 .

Hasil dari penilaian yang diberikan 8 validator dianalisis dengan menggunakan formula Aiken's $V$ untuk mengetahui Validitas LKS Matematika dengan pendekatan saintifik berbasis outdoor untuk siswa kelas IV SD pada materi bangun datar yang dikembangkan.

\section{Tabel 4}

Hasil Analisis Aiken's $V$

\begin{tabular}{|c|c|c|c|c|}
\hline $\begin{array}{c}\text { Aspek } \\
\text { yang } \\
\text { Dinilai }\end{array}$ & Indikator yang Dinilai & $\left|\begin{array}{c}\text { Banya } \\
\mathbf{k} \\
\text { Butir }\end{array}\right|$ & \begin{tabular}{|} 
Angka \\
Aiken's \\
$V$
\end{tabular} & $\begin{array}{c}\text { Kriteria } \\
\text { Koofesie } \\
\text { n Aiken's } \\
\text { V }\end{array}$ \\
\hline \multirow{6}{*}{$\begin{array}{l}\text { Komponen } \\
\text { Kelayakan } \\
\text { Isi }\end{array}$} & Cakupan Materi & 3 & 0,96 & Tinggi \\
\hline & Akurasi Materi & 4 & 0,86 & Tinggi \\
\hline & Pendekatan Saintifik & 7 & 0,99 & Tinggi \\
\hline & Saintifik Berbasis Outdoor & 4 & 0,86 & Tinggi \\
\hline & Mengandung Wawasan Produktifitas & 2 & 0,92 & Tinggi \\
\hline & Merangsang Keingingtahuan & 2 & 0,85 & Tinggi \\
\hline \multirow{4}{*}{$\begin{array}{l}\text { Komponen } \\
\text { Kebahasaan }\end{array}$} & Komunikatif & 1 & 0,96 & Tinggi \\
\hline & Lugas & 2 & 0,94 & Tinggi \\
\hline & $\begin{array}{l}\text { Kesesuaian Dengan Kaidah Bahasa Indonesia } \\
\text { Yang Benar }\end{array}$ & 2 & 0,90 & Tinggi \\
\hline & Penggunaan Istilah Simbol dan Lambang & 2 & 0,88 & Tinggi \\
\hline \multirow{3}{*}{$\begin{array}{l}\text { Komponen } \\
\text { Tampilan }\end{array}$} & Penggunaan Huruf & 2 & 0,92 & Tinggi \\
\hline & Tata Letak Isi Media & 2 & 0,90 & Tinggi \\
\hline & Desain Tampilan & 2 & 0,90 & Tinggi \\
\hline \multirow{3}{*}{$\begin{array}{l}\text { Komponen } \\
\text { Penyajian }\end{array}$} & Teknik Penyajian & 3 & 0,96 & Tinggi \\
\hline & Penyajian Pembelajaran & 5 & 0,90 & Tinggi \\
\hline & Pendukung Penyajian & 4 & 0,92 & Tinggi \\
\hline
\end{tabular}

Dari semua hasil validasi ahli semua item indikator diinpretasikan memiliki koefisien yang tinggi dengan angka sebesar 0,913. Dapat disimpulkan bahwa hasil analisis validasi menyatakan bahwa LKS Matematika dengan pendekatan saintifik berbasis outdoor untuk siswa kelas IV SD pada materi bangun datar yang dikembangkan valid untuk digunakan dalam pembelajaran. 
2. Uji Konsistensi Ahli

Hasil penilaian 8 ahli disajikan dalam tabel berikut:

Tabel 5

Hasil Analisis fo Cohen’s Kappa

\begin{tabular}{|c|c|c|c|c|}
\hline $\begin{array}{l}\text { Aspek yang } \\
\text { Dinilai }\end{array}$ & Indikator yang Dinilai & $\begin{array}{c}\text { Banya } \\
\text { k } \\
\text { Butir }\end{array}$ & $\begin{array}{l}\text { Nilai } \\
\text { Kappa }\end{array}$ & $\begin{array}{c}\text { Level } \\
\text { Kesepakat } \\
\text { an }\end{array}$ \\
\hline \multirow{6}{*}{$\begin{array}{l}\text { Komponen } \\
\text { Kelayakan Isi }\end{array}$} & Cakupan Materi & 3 & 0,88 & Kuat \\
\hline & Akurasi Materi & 4 & 0,59 & Lemah \\
\hline & Pendekatan Saintifik & 7 & 0,84 & Kuat \\
\hline & Saintifik Berbasis Outdoor & 4 & 0,58 & Lemah \\
\hline & $\begin{array}{l}\text { Mengandung Wawasan } \\
\text { Produktifitas }\end{array}$ & 2 & 0,80 & Kuat \\
\hline & Merangsang Keingingtahuan & 2 & 0,55 & Lemah \\
\hline \multirow{4}{*}{$\begin{array}{l}\text { Komponen } \\
\text { Kebahasaan }\end{array}$} & Komunikatif & 1 & 0,90 & Kuat \\
\hline & Lugas & 2 & 0,90 & Kuat \\
\hline & $\begin{array}{l}\text { Kesesuaian Dengan Kaidah Bahasa } \\
\text { Indonesia Yang Benar }\end{array}$ & 2 & 0,90 & Kuat \\
\hline & $\begin{array}{l}\text { Penggunaan Istilah Simbol dan } \\
\text { Lambang }\end{array}$ & 2 & 0,90 & Kuat \\
\hline \multirow{3}{*}{$\begin{array}{l}\text { Komponen } \\
\text { Tampilan }\end{array}$} & Penggunaan Huruf & 2 & 0,80 & Kuat \\
\hline & Tata Letak Isi Media & 2 & 0,70 & Sedang \\
\hline & Desain Tampilan & 2 & 0,55 & Lemah \\
\hline \multirow{3}{*}{$\begin{array}{l}\text { Komponen } \\
\text { Penyajian }\end{array}$} & Teknik Penyajian & 3 & 0,90 & Kuat \\
\hline & Penyajian Pembelajaran & 5 & 0,72 & Sedang \\
\hline & Pendukung Penyajian & 4 & 0,78 & Sedang \\
\hline \multicolumn{3}{|c|}{ Rata-rata } & 0.77 & Sedang \\
\hline
\end{tabular}

Dari data diatas terdapat beberapa item pada aspek yang masih lemah, pada aspek yang pertama yaitu 2 item yang lemah. Pada komponen kebahasaan sudah tergolong kuat. Pada komponen tampilan hanya 1 yang masih lemah. Untuk aspek penyajian dari 3 item tidak ada konsistensi yang lemah

Secara rata-rata nilai Kappa yang didapat adalah 0,77 sehingga dapat disimpulkan bahwa konsistensi ahli yang memberikan penilaian terhadap pengembangan LKS Matematika dengan pendekatan saintifik berbasis outdoor untuk siswa kelas IV SD pada materi bangun datar adalah sedang.

Final produk LKS Matematika setelah divalidasi oleh para ahli disajikan dalam tabel berikut:

Tabel 4.9

Format Penyusunan LKS

\begin{tabular}{|c|l|l|}
\hline No & Unsur LKS & \multicolumn{1}{c|}{ Diskripsi LKS } \\
\hline 1 & $\begin{array}{l}\text { Cover } \\
\text { Depan }\end{array}$ & Halaman depan berisi judul LKS dan Identitas pemilik LKS \\
\hline 2 & $\begin{array}{l}\text { Kata } \\
\text { pengantar }\end{array}$ & Sebagai pengantar dalam penulisan LKS \\
\hline
\end{tabular}




\begin{tabular}{|c|l|l|}
\hline 3 & Daftar isi & Petunjukagar mempermudah menuju kehalaman yang ingin dicari \\
\hline 4 & $\begin{array}{l}\text { Petunjuk } \\
\text { umum }\end{array}$ & Berisi petunjuk bagi siswa dalam penggunaan LKS \\
\hline 5 & $\begin{array}{l}\text { KI, KD \& } \\
\text { Indikator }\end{array}$ & $\begin{array}{l}\text { Muatan materi dalam LKS disusun berdasarkan tujuan } \\
\text { pembelajaran dari analisis KD }\end{array}$ \\
\hline 6 & $\begin{array}{l}\text { Peta } \\
\text { Konsep }\end{array}$ & Berupa peta konsep materi yang tertuang di dalam LKS \\
\hline 7 & Materi & $\begin{array}{l}\text { Materi bangun datar terdiri dari 5 materi yang meliputi: bangun } \\
\text { datar segi banyak, keliling dan luas (persegi, persegi panjang dan } \\
\text { segitiga), dan menaksir luas. }\end{array}$ \\
\hline 9 & $\begin{array}{l}\text { Saintifik } \\
\text { Outdoor }\end{array}$ & $\begin{array}{l}\text { Langkah-langkah pembelajaran diuraikan dengan pendekatan } \\
\text { mencoba dan mengkomunikasikan. } \\
\text { alam sebagai sarana pembelajaran. }\end{array}$ \\
\hline 10 & $\begin{array}{l}\text { Soal latihan } \\
\text { individu }\end{array}$ & $\begin{array}{l}\text { Soal latihan diberikan untuk membiasakan siswa berlatih dalam } \\
\text { memahami materi yang baru dipelajari }\end{array}$ \\
\hline 11 & $\begin{array}{l}\text { Tugas } \\
\text { Individu }\end{array}$ & $\begin{array}{l}\text { Tugas diakhir pembelajaran selama 5 kali pertemuan di berikan } \\
\text { untuk melihat kemampuan peserta didik dalam menguasai materi. }\end{array}$ \\
\hline 13 & $\begin{array}{l}\text { Daftar } \\
\text { Bustaka }\end{array}$ & $\begin{array}{l}\text { Ditulis sebagai referensi dalam penulisan LKS } \\
\text { Sebagai sampul belakang }\end{array}$ \\
\hline
\end{tabular}

Produk final LKS Matematika dengan pendekatan saintifik berbasis outdoor untuk siswa kelas IV SD pada materi bangun datar.

\section{Pembahasan}

Hasil post-test peserta didik yang didapat dari LKS Matematika saintifik berbasis outdoor dapat dikatakan efektif setelah dibandingkan dengan hasil peserta didik dari guru yang menggunakan pembelajaran tanpa menggunakan LKS. adapun hasil dari perbandingan kedua data tersebut adalah sebagai berikut:

\section{Tabel 5}

Hasil Perbandingan Nilai Peserta Didik Yang Menggunakan LKS dengan Yang Tidak Menggunakan LKS

\begin{tabular}{|c|l|c|c|c|}
\hline No & \multicolumn{1}{|c|}{ Nilai Siswa } & Rata-rata Nilai & $\begin{array}{c}\text { Standar } \\
\text { Deviasi }\end{array}$ & $\begin{array}{c}\text { N of } \\
\text { Subjek }\end{array}$ \\
\hline 1 & $\begin{array}{l}\text { Nilai dari treatmen } \\
\text { menggunakan LKS }\end{array}$ & 80,35 & 4,23 & 82 \\
\hline 2 & $\begin{array}{l}\text { Nilai dari Guru tanpa } \\
\text { menggunakan LKS }\end{array}$ & 64,79 & 4,92 & 82 \\
\hline
\end{tabular}

Berdasarkan nilai perbandingan antara rata-rata nilai yang diperoleh peserta didik setelah melakukan pembelajaran menggunakan LKS Matemtika lebih besar dari nilai guru yang melakukan pembelajaran dengan tidak menggunakan LKS Matematika. Terdapat perbedaan dimana nilai rata-rata siswa yang diperoleh setelah melakukan pmebelajaran menggunakan LKS Matematika sebesar 80,35 dan rata-rata nilai siswa yang diberikan pembelajaran tanpa menggunakan LKS Matematika sebesar 64,79.

Dapat ditampilkan juga grafik persentase perbandingan nilai rata-rata yang diperoleh siswa setelah dilakukan pembelajaran dengan menggunakan LKS Matematika dengan nilai siswa yang diberikan pembelajaran tanpa menggunakan 
LKS Matematika. Grafik rata-rata ketuntasan hasil belajar siswa tersebut disajikan dalam bentuk grafik berikut:

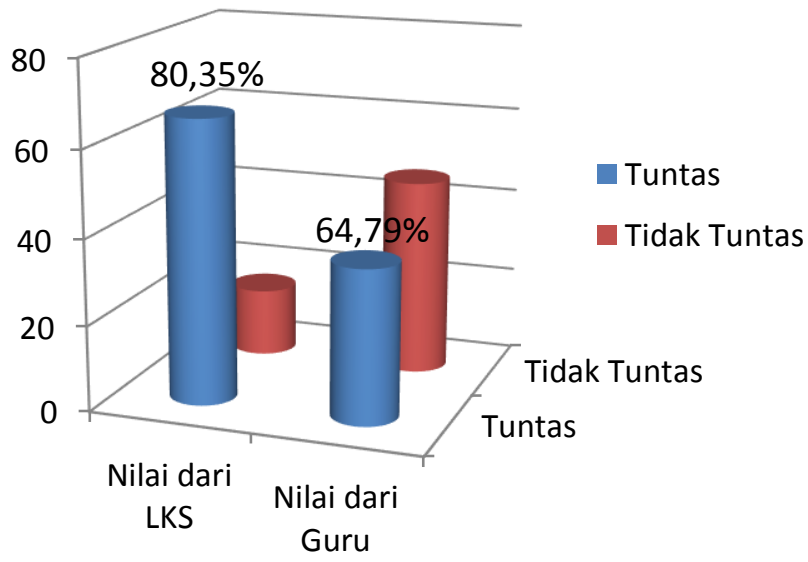

Gambar 3

Grafik Batang Perbandingan Hasil Belajar Peserta Didik

LKS Matematika yang dikembangkan telah dianalisis oleh 8 orang ahli dibidangnya, diantaranya ahli matematika, bahasa, evaluasi pengukuran dan psikologi, evaluasi pembelajaran, media pembelajaran, dan materi matematika. Berdasarkan dari rumusan masalah apakah LKS Matematika dengan pendekatan saintifik berbasis outdoor untuk siswa kelas IV SD pada materi bangun datar, maka validisi ahli perlu dilakukan untuk menguji validitas LKS Matematika yang dikembangkan.

LKS Matematika dikembangkan untuk memenuhi kebutuhan siswa dalam mempelajari materi yang dianggap sulit dipahami dan membosankan. Sebagai pengganti peran pendidik ketika anak belajar secara mandiri, LKS Matematika yang dikembangkan harus valid sebelum digunakan siswa belajar. LKS matemtaika dirancang berdasarkan format penyusunan LKS, diantaranya cover depan, kata pengantar, daftar isi, petunjuk umum, KI, KD, indikator, peta konsep, materi, langkah-langkah saintifik, outdoor learning, soal latihan individu, tugas individu, daftar pustaka dan cover belakang.

Validasi memberikan penilaian dan juga masukan terhadap LKS yang telah dirancang, dari hasil validasi masih banyak kekurangan dan kelemahan LKS yang dikembangkan. Revisi dilakukan sesuai dengan pendapat dan saran ahli yang telah memvalidasi LKS Matematika yang dikembangkan, dari materi pembelajaran yang ada didalam LKS, tata bahasa dan penulisan, tata letak gambar atau animasi yang digunakan, soal-soal yang digunakan dalam evaluasi pembelajaran, dan langkahlangkah saintifik berbasis outdoor.

Kurikulum 2013 saat ini adalah pembelajaran tematik intergratif yang didalamnya terdapat nilai karakter yang harus disematkan dalam kegiatan belajar mengajar, dan hasil belajar yang tidak hanya pada aspek kognitif, tetapi terdapat afektif dan psikomotorik. Langkah-langkah pendekatan saintifik yang digunakan dalam LKS terkonsep jelas seperti yang dinyatakan Daryanto (2014:89), bahwa pendekatan saintifik dalam pembelajaran memerlukan langkah-langkah pokok yaitu meliputi kegiatan mengamati (observing), kegiatan menanya (quastioning), kegiatan menalar (associating), kegiatan mencoba (experimenting), dan kegiatan mengkomunikasikan (networking).

Peserta didik yang melakukan pembelajaran dengan pendekatan saintifik itu membuat pembelajaran berorientasi pada terjadinya peningkatan dan keseimbangan 
antara kompetensi sikap (attitude), keterampilan (skill), dan pengetahuan (knowledge), (Hidayat, 2013:113).

Meskipun masih terdapat kekurangan dalam LKS Matematika dengan pendekatan saintifik berbasis outdoor untuk siswa kelas IV SD pada materi bangun datar yang dikembangkan, validator menilai bahwa penyajian LKS Matematika yang telah didesaian secara keseluruhan valid dan layak untuk digunakan dalam pembelajaran di kelas IV SD karena di dalamnya tergambar pendekatan saintifik berbasis outdoor secara sistematis dan ringkas.

\section{Kesimpulan}

Penelitian ini menghasilkan sebuah prouk baru, yaitu LKS Matematika dengan pendekatan saintifik berbasis outdoor untuk siswa kelas IV SD pada materi bangun datar. Hasil penelitian disimpulkan bahwa LKS Matematika dengan pendekatan saintifik berbasis outdoor untuk siswa kelas IV SD pada materi bangun datar yang dikembangkan valid dan layak digunakan untuk guru dalam mengajar dan untuk pesesrta didik dalam belajar.

\section{Saran}

Berdasarkan hasil penelitian dan kesimpulan, beberapa saran yang dapat diajukan bahwa ntuk membuat suatu LKS Matematika yang valid diharuskan untuk memvalidasi LKS Matematika kepada validator ahli yang benar-benar berkompeten, seperti ahli matematika, ahli materi, ahli bahasa, ahli kurikulum, ahli media, ahli evaluasi, dan ahli psikologi.

\section{Referensi}

Azwar, S. 2015. Reliabilitas dan Validitas. Yogyakarta: Pustaka Pelajar.

Daryanto. 2014. Pendekatan Pembelajaran Saintifik Kurikulum 2013. Yogyakarta: Gavamedia 2014.

Hidayat, A dan Irawan, I. (2017). Pengembangan LKS Berbasis RME dengan Pendekatan Problem Solving untuk Memfasilitasi Kemampuan Pemecahan Masalah Matematis SMA. Universitas Pahlawan Tuanku Tambusai. Jurnal Pendidikan Matematika. Vol.1, No.2, pp, 51-63.

Kunandar, Guru Profesional Implementasi Kurikulum Tingkat Satuan Pendidikan (KTSP) dan Sukse dalam Sertifikasi Guru, (Jakarta: PT Raja Grafindo Persada, 2007)

McHugh, Mary, L. 2012. Interrater Reliability: the Kappa Statistik. Biochemia Medica, Vol. 22, No.3. p: 276-282

Prastowo, A. 2015. Panduan Kreatif Membuat Bahan Ajar Inovatif. Jogjakarta: DIVA Press.

Rodliyah, Z. 2014. Validitas Lembar Kerja Siswa Berorientasi Pendekatan Scientifik pada Materi Sisem Reproduksi Manusia. Jurusan Biologi FMIPA UNESA. Jurnal BioEdu Berkala Ilmiah Pendidikan Biologi. Vol.3, No.3. 2302-9528.

Sugiyono. 2016. Metode Penelitian \& Pengembangan Reseacrh and Development (R\&D). Bandung: Alfabeta. 
Riduan Febriandi

Trianto, 2012. Mendesain Model Pembelajaran Inovatif - Progresif: Konsep dan Implementasinya pada Kurikulum Tingkat Satuan Pendidikan (KTSP). Jakarta: Kencana.

Widiasworo, E. 2017. Strategi \& Mengajar "Mengajar Siswa di Luar Kelas"(Outdoor Learning) Secara Aktif, Kreatif, Inspiratif, dan Komunikatif. Yogyakarta: AR-RUZZ MEDIA 